\title{
Who knows best? Negotiations of knowledge in clinical decision making
}

Charlotte Bredahl Jacobsen, Helle Max Martin \& Vibe Hjelholt Baker ViBIS

charlotte.bredahl.jacobsen.01@regionh.dk, hema@kora.dk,vb@vibis.dk

Jacobsen, C. B., Martin, H. M. \& Baker, V. H. (2015). Who knows best? Negotiations of knowledge in clinical decision making, Tidsskrift for Forskning i Sygdom og Samfund, nr. 22, 67-82

This article examines the conflicts which arise when patients with chronic disease engage in decision making with health professionals about their medication. These are conflicts in the sense of discrepancies or incompatibilities between perceptions or opinions of different people engaged in a common endeavour. The paper is based on three qualitative research studies and presents one case from each study to illustrate analytical findings. Data collected in the original studies consisted of observations of clinical encounters and semi-structured interviews; in total 45 interviews with patients and 23 with health professionals. The analysis shows different conflicts, which arise during the process of making decisions about medication. These conflicts arise when: 1) Patients deliberately hold back information about their medication for fear of challenging clinicians' authority; 2) The decision making process takes place in an environment, which does not support patient involvement; and 3) Patients refer to pharmacological knowledge, but are considered ill-equipped to understand and apply this knowledge by health professionals. The article shows that these conflicts typically revolve around the legitimate access to and use of pharmacological knowledge. These results have important implications for the current discussions of shared decision making. In shared decision making, knowledge about medication is typically regarded as the domain of the doctor. We argue that there is a need for a widening of the concept of partnership, which is central to shared decision making, to encompass breadth of patient knowledge about his/her situation, disease and treatment. Patients with chronic 
diseases need to be actively invited to disclose the extensive clinical knowledge they acquire over time, thereby creating a legitimate space for this knowledge in clinical consultations, and avoiding that conflicts over knowledge domains lead to unnecessary suffering and wasted resources.

\section{Resume}

Denne artikel undersøger de konflikter, som opstår $i$ samarbejdet mellem kronisk syge patienter og deres læger, når der skal træffes beslutninger om deres medicinske behandling. Med konflikter menes uoverensstemmelser mellem to forskellige, oftest uforenelige opfattelser eller meninger hos personer der arbejder mod et fælles mål. Artiklen baserer sig på data fra tre kvalitative empiriske studier af patientinddragelse, herunder observationer af kliniske møder og semistrukturerede interviews; $i$ alt 45 med patienter og 23 med sundhedsprofessionelle. Tre cases fra studierne præsenteres og diskuteres $i$ denne artikel. Analysen afd akkede forskellige konflikter, som opstår i beslutningstagningen omkring medicinsk behandling når 1) patienter tilbageholder information for ikke at udfordre lagens autoritet, 2) beslutningstagningen foregår $i$ et miljø, som ikke understøtter patientinddragelse, og 3) patienter refererer til biomedicinsk viden, men vurderes ude af stand til reelt at kunne forstå og anvende denne type viden. Artiklen viser, at disse konflikter typisk handler om legitim adgang til og brug af viden om medicinsk behandling. Disse resultater er særligt relevante for den aktuelle diskussion om fxlles beslutningstagning. I fxlles beslutningstagning ser vi en tendens til at fastholde den medicinske viden som lægens domæne. På den anden side kan patienters uvilje mod at bringe viden om behandling på banen af frygt for at udfordre lægens autoritet medføre unødig lidelse og ressourcespild. Således synes konceptet frlles beslutningstagning at være delvis inkompatibelt med en række af de forventninger til samspillet, som patienter og sundhedsprofessionelle udspiller i daglig klinisk praksis. Vi argumenterer for, at der er behov for en udvidelse af begrebet partnerskab, som er centralt i frlles beslutningstagning, til at give plads til patientens fulde viden om sin situation, sygdom og behandling. Kronisk syge patienter skal inviteres eksplicit til at dele den kliniske viden, de har opbygget over tid for herved at skabe et legitimt rum for denne viden $i$ konsultationer, og undgå at konflikter over vidensdomæner fører til unødvendig lidelse og ressourcespild.

\section{Keywords}

Patient Participation, Shared Decision Making, Communication, Knowledge, Chronic Illness Management, Qualitative. 


\section{Introduction}

During the last two decades the concept of patient participation has become increasingly important in Danish health care. Patient participation implies that patients are both central objects of health care services, and also agents with particular knowledge and resources, which should be taken into account when decisions about their care are made. Thus, patients are no longer perceived as passive recipients of care, but are expected to engage actively in the management of their disease $^{1}$. Being active partners in health care require that patients are more involved in and responsible for the various processes of their care, including monitoring symptoms, seeking appropriate and timely medical assistance, engaging in dialogue with health professionals, stating their care preferences, and making informed choices (Coulter \& Ellins 2006). Indeed, good clinical practice is increasingly envisioned as a process, in which clinical facts about the disease and its treatment are attuned to the psycho-social background, treatment preferences and illness perceptions of the individual patient. This view is expressed perhaps most strongly in the concept of shared decision making (Coulter \& Ellins 2006; Jacobsen, Pedersen, \& Albeck 2008; Sheridan, Harris, \& Woolf 2004).

In a report on shared decision making targeting clinicians, Coulter and Collins defines the core of SDM as 'the recognition that clinicians and patients bring different but equally important forms of expertise to the decision-making process' (Coulter \& Collins 2011:2). They explain that the clinician's expertise is based on knowledge of the diagnosis, likely prognosis, treatment and support options, and the range of possible outcomes based on population data. In contrast, patients' expertise consists of their knowledge of how their disease and treatment impact on their daily life, their personal attitude to risk and their values and preferences (Coulter \& Collins 2011). According to Coulter and Collins, shared decision-making implies that both types of expertise are taken into account, and that decisions about treatment and care are reached through agreement and informed by research evidence.

The increasing focus on patient participation, and shared decision making in particular, marks a shift in the conceptualisation of the dialogue with the patient in medicine. Since the late 80's, the ideal communication between doctor and patient has been conceptualised as one of dialogue and involvement, as opposed to one of merely information and consent (Zinck Pedersen 2008). However, the ideal of dialogue and sharing of equally important forms of knowledge may mask what Grimen (2009) calls 'the nexus of power, trust and risk'; i.e. that patients depend on doctors' professional expertise concerning for instance the risks and benefits 
of available treatment options and their position as gatekeepers controlling access to treatment, and the inferiority that follows from this dependence (Grimen 2009).

Much in line with this critique, qualitative studies have documented a number of patient-related barriers to shared decision making. Among these are patients' expectations to the clinical encounter; for instance some patients believe that 'normal' patients are mostly passive and receiving, and that clinical decisions should be based only on the expert knowledge of the clinician; others believe the way to get high-quality treatment is to get the doctor on their side by being 'good patients', who do not take up too much of the doctors' time or challenge their authority (Joseph-Williams et al. 2014).

Patients with chronic disease often gain detailed insights about their disease and treatment. These insights span the experience of living with and managing chronic disease, the experience of disease progression and their body's response to medication. In the process they often learn how to interpret medical information relevant to their condition. Thus, the knowledge they glean from their situation is subjective, but they often also gain significant insight into biomedical knowledge about their disease and medication, which may be highly relevant in the clinical encounter.

This article describes the conflicts which sometimes occur when patients with chronic disease attempt to participate in decision making about pharmacological treatment, i.e. the domain at the heart of clinicians' expertise. Thus it contributes to current discussions on shared decision making and the barriers for its implementation (Elwyn et al. 2013). It argues that there is a need for creating a legitimate space for patients' knowledge about their medication in clinical consultations in order to avoid conflicts over knowledge domains, which can otherwise become barriers to the realisation of patient involvement in general and shared decision making in particular.

\section{Methods}

The empirical background for this article is three qualitative studies about patient-centred health care in Danish hospitals: A study on shared decision-making in heart rehabilitation and arthritis care (Jacobsen et al. 2008); a study on the implementation of patient participation in everyday clinical practice among patients and their relatives in a neurology department (Jacobsen \& Petersen 2009); and a 
study on the experience of continuity of care among patients with diabetes, cancer and heart disease (Martin 2010).

Data from the three studies comprised observations during consultations, ward rounds, waiting time etc., as well as interviews and/or focus groups with patients and health professionals about their experiences with patient participation. A total of 45 patients and 23 health care professionals were interviewed in the three studies. In addition, 35 health professionals participated in focus groups in the study by Martin (2010). For the purpose of this article, we present three rich individual cases, illuminating central themes in the data. Each case illustrates an encounter between a patient and health professionals involved in their treatment. Although the diseases and situations of the patients varied, the cases represent different ways in which patients employ knowledge about their disease and/or medication in the clinical encounter.

\section{Cases}

\section{Case 1: When patient knowledge is withheld}

Peter is in his 60s and has suffered from Parkinson's disease for more than 10 years. He recently had a heart attack and was subsequently diagnosed with ischemic heart disease. He takes medication to control the symptoms of Parkinson (mainly body stiffness and pains in muscles and joints), and to prevent another heart attack (an anti-coagulant called Warafin). Peter is admitted for surgery to have an intestinal medicine infusion pump which can dose his Parkinson medication more precisely. He arrives at the ward in the morning and sees the surgeon for his admission consultation. After reading his journal and asking Peter, the surgeon realises that Peter is still taking Warafin. Anti-coagulants increase the risk of serious bleeding and is contraindicated before an operation. The operation is therefore postponed until the effect of the drug has worn off. Peter is kept on the ward, as the health professionals assume that he will be ready for operation the following day. However, it proves difficult to estimate exactly when the effect of the medication has worn off, and the operation is postponed three times. Each time Peter has to fast and is told not to take his Parkinson medication. Consequently, the planned operation causes Peter's Parkinson symptoms to flare up, with the result that he is in great pain for some time. The staff and Peter have different opinions as to 
who is to blame for this situation: A nurse talking to her colleagues blames Peter for 'being so forgetful', and not telling the doctor about his medication well in advance of the planned operation. When the nurse is measuring his blood pressure, Peter blames the doctor for having forgotten about the Warafin. But as the nurse leaves, Peter says to himself and the researcher besides him: "I knew it. I did. But I didn't want to interfere in their affairs. I didn't want to play the doctor."

Peter's last comment tells us that there is more at stake than simple lapse of memory. Peter was aware that Warafin should not be taken before an operation. In the interview later on he blames himself for not having asked the doctor about the Warafin before he was admitted for the operation.

Peter: "I should not have taken Warafin, but I didn't want to ask" (continues in a feigned childish voice): 'should I then continue with Warafin?'”

Interviewer: "So you had thought about it?

Peter: "Yes, of course, you can't even go to the dentist when taking Warafin."

Peter points to an important issue. He suggests that it may be considered inappropriate for patients to bring forth their knowledge if it interferes with the doctor's professional knowledge.

Peter mimics a child's voice as he poses the question he never asked during the consultation. His imitation defines the child's position as one of ignorance and submission. Although Peter has years of experience with his disease and his medication, he does not want to 'play the doctor' and claim authority, but refrains from voicing his concern. By not mentioning Warafin, Peter acknowledges the exclusive right of the doctor to possess and act upon biomedical knowledge, and assumes that his participation would be an undue interference with the doctor's professional domain.

Strauss et al. have claimed that health professionals continuously judge the actions of their patients (Strauss, Fagerhaugh, Suczek, \& Wiener 1997). They may see patients' 'work' ${ }^{2}$ as good or bad, rational or irrational, sensible or foolish etc. As Peter's case illustrates, patients are aware of this judgement of their actions, and they assume that the health care professionals perceive them as 'good' or 'bad' patients, depending on how they behave. Therefore, many patients endeavour to communicate in a way they think will minimize conflict and maintain a good relationship with the health professionals. In line with Grimen's point that the power of doctors is related to access to treatment, many of the patients who 
participated in the three research studies believed that they would obtain better treatment if the health professionals viewed them in a positive light. Behaving as a good patient, i.e. as they thought the health professionals expected them to act, therefore became an important strategy.

Peter's case illustrates that the separation of clinicians' and patients' areas of expertise are, at least in part, instigated and reproduced by patients. This can be seen as an example of collusion - a tacit, sometimes not quite conscious, agreement between different actors to behave and communicate in ways that maintain the social order and avoid any behaviour or statements that would break it. In the case above, Peter makes sure that he does not challenge the doctor's position as biomedical expert, and acts in a way he assumes is considered appropriate in a hospital: the cooperative patient who commits himself fully to hospital care. In this way, potential conflict is avoided and social order is maintained. Unfortunately, this order comes at a cost. Peter is frustrated with the way preparations for his surgery took place, which he sees as partly his own fault. Indeed, his case represents the unfortunate consequences of this submissive approach: because of his unwillingness 'to interfere' he had to endure a week of pains and disappointment.

\section{Case 2: When patient knowledge is disregarded}

Jane, a woman in her 40s, has had diabetes (type I) for 25 years. She takes her disease very seriously and carefully manages her blood sugar levels. At the time of the interview she had been admitted to hospital for four days to undergo reconstructive surgery of a painful scar in the groin. During the interview, it becomes clear that although the clinical staff was nice and efficient, she found that their management of her insulin injections during her admittance was below standard. It was not the first time she experienced inadequate diabetic care from hospital staff outside the endocrinology department:

"Every time I've been admitted my blood sugar goes out of control. I think there is a rule that you cannot take your own medicine when you're in the hospital. The staff is supposed to give it to you, but a surgical department is a bit like a slaughterhouse - they know how to operate, but they don't know much about diabetes. So this is a problem when you have a chronic disease and have your check-ups in a different department where you are seen regularly and they know you very well, because the departments do not cooperate. The left hand doesn't know what the right hand does. So why not ask the patient? I have had diabetes for 25 years. I could have told them what to do. But what happened was that the night before the 
operation the night nurses forgot to check my blood sugar level and at five in the morning I had a hypo. Then they gave me something sweet to drink and my blood sugar became far too high which is really bad when you're going in for surgery. So during the operation they had to give me a lot of insulin and I felt very bad afterwards. Those four days were really turbulent. If they had asked me - and I tried to tell them many times - then I needn't have had that bad experience. To be honest, I also relaxed and trusted them because they seemed to be in control. I was nervous about the operation and was happy that they could take over a bit. I became very frustrated when I found out that they didn't know how to do it. Afterwards I pointed out that they should consider doing things differently next time. Surely, I'm not the only patient with diabetes in their department. It's not like I was annoyed or anything, and it was meant as a constructive comment to help other patients in the same situation, but the nurses just looked at me like I had no right to say that." (edited account)

Administering insulin is a daily task for type 1 diabetics. People who live with diabetes for many years acquire extensive factual and experiential knowledge about their condition, its treatment, and how their body responds to it. Jane, who has had diabetes for 25 years, is an expert on her condition, and has been encouraged to think of herself that way at the biannual check-ups with her endocrinologist. Her willingness to take responsibility is something she emphasizes in the interview.

However, her knowledge is not recognised by the health professionals in the surgery department. Instead, they take over the glycaemic control of diabetic patients and follow a generic schedule for insulin injections. This is standard procedure when patients with diabetes are admitted to the department. In the interview, Jane recounts how she has initial doubts about the quality of this treatment approach, but that she also acknowledges the medical authority of the doctors and nurses she meets and therefore surrenders control of her diabetes to them.

Jane's case illustrates that the ideal of the active, responsible patient may not be compatible with the reality of decision making in all medical areas and situations. The active patient role advocated in the principle of patient participation applies easily to an outpatient department where treatment and care is centred around patients' self-management of their condition. But the institutional framework of the surgery department contributes to the passivity of diabetic patients by encouraging them to give up responsibility for the medication management.

Jane is keen to present herself as a 'strong patient', who is not afraid to voice her needs when talking to health care professionals and who knows how to obtain the services she considers necessary for her treatment. As such, she is indeed a good 
example of the active patient. Unlike Peter, she expresses her opinion about her treatment and care, and is not afraid to point out failures or suggest procedural changes to both nurses and doctors. Yet at the same time, she emphasizes that her aim is not to complain, but simply to get help in her pursuit of care, and that she has always been very friendly and tried not to annoy the doctors. By acting this way, she pursues two strategies simultaneously: 1) She takes responsibility, asserts her needs and presents her perspective, while also 2) acknowledging an institutional hierarchy in which the patient is dependent on the health professionals and thereby constitutes the lowest level. These two strategies allow Jane to simultaneously maintain and challenge the social order that defines the doctor as the knowledgeable authority and the patient as passive and 'unknowing'.

\section{Case 3: When patient knowledge leads to conflict}

The last case is from an arthritis outpatient clinic. Arthritis cannot be cured and so treatment is focused on controlling symptoms, i.e. reducing pain and minimizing the deterioration of bones and joints. When symptoms and objective disease markers change and warrants adjustments of medication, patient knowledge and professional knowledge needs to be exchanged. Blood tests, scans and mobility tests are employed to obtain an overview of symptoms and make decisions about medication. But patients' subjective evaluations of pain and the effect of the treatment contribute crucial information to the process of medical decision-making. However, if the boundaries between knowledge domains become blurred this exchange may become conflictual. This was the case in the consultation with Bettina who is a middle-aged woman who has been treated for arthritis in the clinic for a couple of years. Prior to the consultation, the researcher observes the doctor preparing for the consultation. The doctor reads the patient file and notes that Bettina does not receive the clinic's first-choice treatment. The doctor consults her colleague who encourages her to change the patient's treatment. During the consultation, the doctor tries to persuade Bettina to change medication:

Doctor: "I can see you take Salazopyrin. Was it your own choice?"

Betina: "No. I had a lot of problems with my arthritis, and that is why I got it."

Doctor: "The results of your blood test show signs of activity. It shows 36." 
Bettina: "The last time I was here, the doctor told me that the activity goes up with age. What was my CRP? Can I have a copy of the blood test results? I am a laboratory technician so I can understand them."

Doctors: "Yes, you may. The activity rises as one grows older, that is correct. However, we must try to keep it low; that is what's important. I have talked to my colleague about it and we agree that it would be a good idea for you to change treatment to Methotrexate."

Bettina: "But I am happy with the treatment I get now."

Doctor: "We prefer Methotrexate because it has been proven to increase survival. That is why it is our first-choice treatment."

Bettina: "The other doctor told me to take Salazopyrin for a couple of years and by then we would see if there was any activity."

Doctor: "I want you to know why Methotrexate is our first choice, but if you do not want it then..."

Bettina: "No I don't!"

Doctor: "You don't want to change medicine, but you also take lower doses now than you did at the beginning. I am not happy with that."

Bettina: "I take two pills a day. I don't want more unless there are changes in the blood test results."

Doctor: “When I look at your results, I can see you're undertreated. You think in terms of biochemistry because you are a lab technician, but not everything can be registered biochemically. When you get an ultrasound scan, the nurse will also count the number of sore joints. That is what I am looking at. I don't look at the blood tests alone."

Bettina: “Ok, so how many Salazopyrin should I take? Am I to continue with two?

Doctor: "If you want to."

Bettina: “Ok, then let's say that I continue with two until the ultrasound scan and then we can reconsider?" 
It is clear from this quote that Bettina has a strong preference for the medicine she takes, and she argues her case by referring to clinical factors such as her blood test results rather than her personal experience of pain or side effects. The doctor deflects Bettina's knowledge of blood tests by referring to the importance of other clinical information - ultrasound scans and soreness of joints - which only the doctor can interpret. Bettina demands that the decision is made on the basis of test results rather than the doctor's assessment. The atmosphere during the consultation grows tense. Not only the dialogue, but also gestures, facial expression and tone of voice indicate that there is a conflict over the choice of medication.

After the consultation the doctor explains to the researcher that she thinks it is problematic, when patients think they have expert knowledge, because managing arthritis is a very complex and demanding field even for doctors who specialize in it. The doctor sees Bettina's unwillingness to change medication as an irrational fear of the side-effects of cytotoxic drugs, which many patients know are also used in cancer treatment (i.e. chemotherapy ${ }^{4}$ ), although in much higher doses. The doctor sums up:

"So with her I have a really hard time providing informed treatment. It is much easier with the kind of patients to whom I can explain what I can and what I cannot do. And also, when my colleagues ask why she is given Salazopyrin... I will have to write in the journal that it was HER choice and that she does not want the Methrotrexate treatment even though we all know she ought to have it ... She is typical for the patients who are difficult to get involved because she is so prejudiced."

The example illustrates that this particular patient is considered 'trespassing' when she states her treatment preferences with reference to clinical knowledge. It also illustrates the lack of agreement about what patient participation and dialogue is in practice. While the doctor agrees that patient participation is legitimate to this type of consultation, she seems to be expecting a kind of participation which is similar to a more traditional paternalistic approach to clinical decisionmaking. She expects that when she puts forward her opinion on the right choice of medication, the patient will accept this as the right choice. Similar findings are described by Stone (1997) in a study of diabetes care, where clinicians perceived patients' way of participating as illegitimate challenges to their professional expertise, which obstructed proper clinical practice. 
In this case, the doctor's comments emphasize her superior claim to the clinical knowledge domain.

\section{Discussion}

This article presents three cases about patients, who were involved in negotiations over legitimate use of different types of knowledge: Peter withheld information about his medication to avoid making what he saw as illegitimate claims to the doctor's knowledge domain. Jane experienced how her skills and knowledge about the management of her diabetes were overruled by work routines in the surgical ward. And Bettina's doctor perceived her attempt to engage in decisionmaking about her medication as a communication breakdown, which prevented her from getting the best possible treatment, seen from a clinical perspective.

The patients all describe themselves as active and responsible patients, as did the majority of participants in the three studies. People construct personal narratives in accordance with the cultural norms and ideals they are surrounded by (see for instance Taylor 1989). It is therefore not surprising that patients with chronic illnesses construct their narratives of self and health in accordance with dominant ideals of responsibility, active engagement and participation, and recognize the necessity of taking responsibility both at home and in the clinical encounter. However, acting the responsible, participating patient appears to be difficult in some clinical situations. The cases presented in this paper illustrate that patients navigate between expectations of being active and responsible patients, and the more passive patient role which they are offered in certain clinical situations. This paradox requires a constant negotiation of strategies, which becomes most visible when the patients attempt to interfere with the professional domain of pharmacological treatment. Choosing how to treat a given disease with medication is arguably among the most important and challenging areas of clinical decision-making. Yet, several studies have found that, despite interest in the principles of shared decision making on policy making level, patients rarely participate actively in decisions about their treatment (Makoul, Arntson, \& Schofield 1995; Stevenson, Barry, Britten, Barber, \& Bradley 2000; The Health Foundation 2012; Coulter \& Collins 2011). Partly, this could be due to structural barriers - lack of time, changing doctors, standardization of care etc. However, patients may also refrain from participating in decision making because they are cautious about challenging clinical authority. In their book about the social life of medicines, Whyte et al. (2002) argue 
that drugs are the essence of medical practice, and therefore a symbolic extension of the doctor (Whyte, Van der Geest, \& Hardon 2002). Thus, in writing a prescription the doctor exercises his professional authority and distances himself form the lay person. This gives the doctor a very specific power in the clinical encounter with the patient. When patients wish to have a say in the choice of medicine, like Bettina did, they not only venture into a domain that traditionally belongs exclusively to the doctor. This can be interpreted as an implicit challenge to the doctor's professional authority in the clinical encounter. Ainsworth-Vaughn (1998) points out that a patient's deference does not necessarily imply passivity or a lack of active engagement in the treatment process (Ainsworth-Vaughn 1998). When being admitted to hospital wards, people find themselves in an unfamiliar place with their health at stake. They are therefore likely to be very cautious of indications about expected behaviour in different situations. If patients assume that health professionals who approve of their behaviour are more likely to treat them well, they will find themselves in a double bind of opposite risks: On the one hand, disagreeing about knowledge could anger health professionals and hypothetically lead to sub-optimal care. And on the other hand, withholding information about their medication and symptoms could lead to complications in their treatment. When Peter, Jane and Bettina weigh up the benefits and risks of sharing their knowledge of medication in a clinical encounter, they do so because they are well aware that when it comes to the prescription of medication, they enter a domain, which is at the heart of physician competence and authority. The cases thus show that it can be difficult for patients to participate in decision making about pharmacological treatment if they make use of clinical knowledge, and if their participation is not explicitly invited and welcomed by health professionals.

\section{Concluding remarks}

This article raises questions about how principles of patient participation can be implemented in practice: Who has legitimate right to use which kinds of knowledge? Who is competent to make which kind of judgments? How can patients and health professionals solve disagreements about treatment to the satisfaction of both parties?

These questions are not least important for the current interest in implementing the principles of shared decision making in clinical practice across health care systems. In the discourse of shared decision making, patient knowledge is un- 
derstood as the extensive knowledge about his/her own everyday life and illness. However, it may be relevant for patients with chronic disease to refer not only to this type of knowledge, but also to the knowledge about medication they may have acquired through long term management of their condition(s). Our studies show that the ideal of open dialogue, equality and partnership between patients and health professionals nevertheless award limited space for patients' knowledge about medication. Unfortunately, withheld or incorrect knowledge about medication can lead to treatment delays and unnecessary suffering for patients, resulting in wasted resources. One way to overcome this issue is to invite patients to bring their clinical knowledge forward in the same way they are invited to bring forward their knowledge of living with their disease, their perceptions of risk, their treatment preferences etc.

If patients' clinical knowledge is to have a place in the doctor-patient communication, doctors will have to actively invite them to disclose this knowledge. As our cases show, patients may be very reluctant to venture into clinical territory. One step towards this goal could be a widening of the notion of shared decision making to extend the concept of partnership to encompass the extensive clinical knowledge that some patients with chronic disease acquire over time. Seeing the doctor and patient as partners does not mean that their roles are interchangeable or their knowledge the same. In its ideal sense, the concept of partnership implies a respectful dialogue that includes the knowledge and perspectives of both patient and health professional. Seen this way, the question of 'who knows best' may be less relevant. Instead we should start asking 'how can doctors - expertise and authority intact - make space for the full breadth of patient knowledge? With the ultimate goal of better treatment.

\section{Acknowledgements}

This research was funded by the following Danish charities and organisations: Det Kommunale Momsfond, Apotekerfondet af 1991, Gigtforeningen, Sygekassernes Helsefond, Sundhedsstyrelsen, Enhed for MTV, the Danish Enterprise and Construction Authority, the Danish Cancer Society and DSI. Ethical approval was given locally at each individual hospital in accordance with Danish health legislation about social science research within the health sector. Patients and health professionals who participated in interviews were given information sheets explaining the study, and signed a written consent form. The authors are grateful to 
the patients and the health professionals who took time to talk to us in all three studies, and to Anja Petersen, who collected the case about Peter as she took part in one of the original studies.

\section{Notes}

1: Another aspect of patient participation concerns the evaluation and improvement of health care delivery through the monitoring of patient satisfaction with the services they encounter (Coulter \& Ellins 2006)

2: Strauss terms all the actions of patients in relation to treatment as 'work' and considers this comparable to the work of health professionals.

3: 'Hypo' is short for hypoglycaemic episode.

4: Methotraxate is used in high doses in cancer treatment, but also in low doses when treating for instance arthritis. It is usually well tolerated in low doses, while adverse drug reactions (incl., nausea, vomiting, diarrhea and fatigue) are more common in high doses.

\section{References}

Ainsworth-Vaughn, N. (1998). Claiming Power in Doctor-Patient Talk. Oxford: Oxford University Press.

Andersson, S. (2000). I en klasse for sig. København: Nordisk Forlag.

Baarts, C. (1998). Her er vi alle ens. Om lighed og forskellighed $i$ kommunikation mellem patienter og behandlere. København: Institut for Antropologi, Københavns Universitet.

Coulter, A. \& Ellins, J. (2006). Patient-focused Interventions: A review of the evidence. London: The Health Foundation.

Coulter, A. \& Collins, A. (2011). Making Shared Decision-making a Reality. No decision about me, without me. London: Kings Fund.

Elwyn, G. et al. (2013). "Many miles to go...": a systematic review of the implementation of patient decision support interventions into routine clinical practice. BMC Medical Informatics and Decision Making 13(suppl2):514.

Grimen, H. (2009). Power trust and risk. Medical Anthropology Quarterly 23(1), pp.16-33.

Hall, S. (2001). Foucault. Power, knowledge and discourse. In: Discourse Theory and Practice: A Reader (pp. 72-81). London: Sage.

The Health Foundation (2012). Helping people share decision making. A review of the evidence considering wheter shared decision making is worthwhile. London: the Health Foundation.

Jacobsen, C. B., Pedersen, V. H. \& Albeck, C. (2008). Patientinddragelse mellem ideal og virkelighed. En empirisk undersøgelse af frlles beslutningstagning og dagligdagens møder mellem patient og behandler. København: Sundhedsstyrelsen, Enhed for MTV og Dansk Sundhedsinstitut. 
Jacobsen, C. B. \& Petersen, A. (2009). At skabe muligheder for brugerinddragelse i daglig klinisk praksis (FOKUS nr. 36). København: Forum for Kvalitet og Udvikling i Offentlig Service.

Joseph-Williams et al. (2014): Knowledge is not power for patients. A systematic review and synthesis of patient-reported barriers and facilitators to shared decision making. Patient Ecuation and Counselling, 94, pp. 291-309.

Makoul, G., Arntson, P., \& Schofield, T. (1995). Health promotion in primary care: physician-patient communication and decision making about prescription medications. Social Science \& Medicine, 41(9), pp. 1241-1254.

Martin, H. M. (2010), Er der styr på mig? Sammenhængende patientforløb fra patientens perspektiv, Danish Institute for Health Services Research, Copenhagen.

Salmon, P. \& Hall, G.M. (2003). Patient empowerment and control: a psychological discourse in the service of medicine. Social Science \& Medicine, 57(10), pp. 1969-1980.

Sheridan, S.L., Harris, R.P., \& Woolf, S.H. (2004). Shared decision making about screening and chemoprevention. a suggested approach from the U.S. Preventive Services Task Force. American Journal of Preventive Medicine, 26(1), pp. 56-66.

Stevenson, F.A., Barry, C.A., Britten, N., Barber, N., \& Bradley, C.P. (2000). Doctor-patient communication about drugs: the evidence for shared decision making. Social Science $\mathcal{E}$ Medicine, 50(6), pp. 829-840.

Stone, M.S. (1997). In search of patient agency in the rhetoric of diabetes care. Technical Communication Quarterly, 6(2), pp. 201-217.

Strauss, A., Fagerhaugh, S., Suczek, B., \& Wiener, C. (1997). Social Organization of Medical Work. New Brunswick: Transaction Publishers.

Taylor, C. (1989). Sources of the Self. Massachusetts: Harvard University Press.

Zinck Pedersen, K. (2008). Patientens politiske diskurshistorie. Research Report. Copenhagen Business School.

Whyte, S.R., Van der Geest, S., \& Hardon, A. (2002). Social Lives of Medicines. Cambridge: Cambridge University Press. 